\title{
Study of some physiological, productive and microbial parameters of goat kids feed kefir milk
}

\author{
${ }^{1}$ Tabarek K. Al-Ghazi , ${ }^{2}$ Meitham K, AL-Galiby \\ ${ }^{I}$ College of Agriculture \&marshes University of Thi Qar \\ ${ }^{1}$ Email:Tbirq14@gmail.com
}

\begin{abstract}
:
This study was conducted in the animal farm of the College of Agriculture and Marshes / University of Dhi Qar for the period from 6/11/2020 to 16/2/2021 to study the effect of using different levels of kefir milk on the performance of local goats kids. The study included (16) local males kids of Iraqi Local goats. And the experiment lasted 100 days. Introductory 16 day of adapt.The goats were taken after weaning at the age of 3-4 months with an average weight of $(19.59 \pm 2.81) \mathrm{kg}$. They were purchased from the local markets and were examined by the veterinarian to ensure their safety and free from diseases. The goats were randomly divided into four groups with four kids for each group. The feed was provided as $3 \%$ of the live body weight. The quantities of feed provided were adjusted every two weeks based on the new mean weight of each group. The experimental animals were randomly divided into four treatments
\end{abstract}

\section{INTRODUCTION}

The specific areas for fodder cultivation in most countries of the third world, including Iraq, are limited and few. This leads to a clear shortage of green fodder materials, which necessarily leads to the use of residues and residues of agricultural and industrial crops such as wild reeds, hay, palm fronds, dates and other fodder alternatives with The low nutritional value, and the lack of these materials for digestible energy and protein and the high percentage of carbohydrates associated with lignin are among the main problems that these materials suffer from. This is in addition to double the amount eaten, and based on all these reasons, the nutritional value of these materials is considered low. Several attempts have been made to improve the digestibility of poor quality forages using various food additives (Nagpal et al., 2007). Thus, it is possible to increase the possibility of using these feeds to feed ruminants by improving their nutritional value in order to fill the shortage in rough fodder and increase the utilization of agricultural and industrial crop residues in feeding ruminants, including goats. Probiotics that are nutritional supplements containing potentially beneficial bacteria and yeast, which are believed to provide health benefits to the host (Fuller, 1989) have been used to improve the nutritional value of feed as direct food additives, including kefir. Kefir: An ancient fermented milk product with a sour taste and refreshing aroma, originating from the mountains of the North Caucasus in Russia. It has been common in Russia and Central Asian countries such as Kazakhstan and Kyrgyzstan for several centuries (Otles et al. 2003). And kefir gradually spread to Japan, the United States and some European countries (Ahmed et al., 2013), which has become one of the most popular fermented dairy products today. Milk is used as the main fermented material

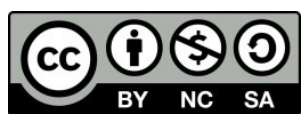

Page68

UTJagr This is an open access article under the CC-BY-NC-SA license (https://creativecommons.org/licenses/by-nc-sa/) 
by kind of using a kind of irregular granular starter or kefir grain to make kefir. Kefir grains are milky white to creamy and naturally shaped. The intricately folded surface makes it look like a cauliflower with a size of 0.5-3.5 cm (Farnworth, 2005). Kefir is considered an organism in which inactive natural microorganisms coexist, some lactic acid bacteria, acetic acid bacteria and yeasts are grown in kefir grains. These bacteria and yeasts are surrounded by a group of water-soluble polysaccharides, which are named kefiran (Enikeev, 2012; Hsieh et al, 2012; Irigoyen et al, 2005,). In the kefir production process a mixture of flavoring substances such as lactic acid, ethanol, carbon dioxide, and acetaldehyde is formed at the same time that lactate and alcohol are fermented into lactose simultaneously (Güzelseydim et al, 2000). It also contains many antioxidants in addition to its various therapeutic properties. It is also rich in amino acids and in vitamins B2, B12, A, D and $\mathrm{K}$, in addition to enzymes and minerals, especially calcium, phosphorous and magnesium (Farnworth, 2005; Lopitz-Otsoa et al., 2006; Golowczyc). et al., 2007; Gaware et al., 2011; Haghpanah et al., 2012.). And fermented kefir milk has not only a unique taste, but also many functions of various probiotics. The properties of probiotics and prebiotics, as it is considered anti-microbial, anti-cancer and anti-diabetic. It has also been verified as having anti-allergic properties in several studies (Güzelseydim et al, 2011), which is mainly due to the nutrients in the liquid milk itself and the metabolites secreted by microorganisms. The microbial and chemical properties of kefir can be influenced by several factors such as the quality of the initiator and fermentation conditions (Wszolek et al., 2001). There is evidence that one of the reasons for the general longevity of the population in the Caucasus is the long-term consumption of kefir dairy products

\section{MATERIALS AND METHODS}

This study was conducted in the field of the College of Agriculture and Marshlands / University of Dhi Qar for the period from $11 / 6 / 2020$ to $16 / 2 / 2021$. The study included (16) animals of male goats who took the camels after weaning at the age of 4 months with an average weight of $19.2 \mathrm{~kg}$. They were purchased from local markets and checked by the vet to ensure they are safe and disease-free. The goats were randomly distributed among four equal groups (4 children/group) after their initial weights were recorded. The goats' weights were taken every two weeks for the duration of the study using a digital scale, and all transactions were fed on a concentrated diet consisting of (25\% barley, $25 \%$ wheat bran , $20 \%$ flour, $20 \%$ yellow corn, $7 \%$ soybean meal, $3 \%$ salts and vitamins (premix). The study groups were fed a diet of the above-mentioned ingredients at the rate of $3 \%$ of the live body weight of each animal in addition to wheat straw as well as To treatment with kefir milk.

T1 - (control group) 3\% concentrated feed + dry filler feed (wheat hay).

T2- (the second treatment) 3\% concentrated feed + dry filled feed + kefir dose $40 \mathrm{ml}$ per day.

T3- (the second treatment) 3\% concentrated feed + dry filled feed + kefir dose $60 \mathrm{ml}$ per day.

T4- (the second treatment) 3\% concentrated feed + dry filled feed + kefir dose $80 \mathrm{ml}$ per day

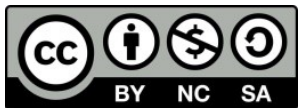




\section{RESULTS AND DISCUSSION}

\section{The weight of the goats}

The product weights of the different experimental treatments in different stages of kefir milk during the 12 -week study period show there are significant differences in the weights of different kefir despite the presence of an arithmetic increase with the product of different treatments control and comparison of $40 \mathrm{ml}$ of kefir milk / head / day and $60 \mathrm{ml}$ of kefir milk / A head / day and $80 \mathrm{ml}$ of milk kefir / head / day $(22.40,25.02,26.59,25.12) \mathrm{kg}$ and from the observation of values and from the observation of values and values we find our values we find the arithmetic in the final weight of the treatment $60 \mathrm{ml}$ of milk kefir / head / day followed by the treatment $40 \mathrm{ml} \mathrm{Kefir} \mathrm{milk/} \mathrm{head} \mathrm{/} \mathrm{day} \mathrm{of} \mathrm{treatment} 80 \mathrm{ml}$ Milk Kefir / head / day of treatment, conditions and the increase in the number of microorganisms in it, especially the total and decomposing bacteria of cellulose, which increases the utilization of nutrients intake and increase the proportion of microbial protein. Natural additives and compounds adjacent to natural kafir, and the study agreed with Ahmed and others (2016), Abu Salwa (2016), Al-Ghalbi and others (2017, a) and Elaref) and others 2020).

Table (4) Average body weight of goats. Group of animals and groups that dosed different levels of kefir milk throughout the study ( \pm standard deviation)

\begin{tabular}{|c|c|c|c|c|c|c|c|}
\hline animal & ghts & & & & & & \\
\hline the weel & & & & & & & Iransac \\
\hline 12 & 10 & 8 & 6 & 4 & 2 & 0 & \\
\hline $\begin{array}{l}22.40 \pm \\
2.33\end{array}$ & $\begin{array}{l}21.92 \pm 3 \\
.56\end{array}$ & $\begin{array}{l}21.46 \pm 2 \\
.29\end{array}$ & $\begin{array}{l}21.17 \pm 2 \\
.07\end{array}$ & $\begin{array}{l}19.80 \pm 2 \\
.34\end{array}$ & $\begin{array}{l}19.10 \\
\pm 2.68 \\
\end{array}$ & $\begin{array}{l}18.35 \pm \\
3.08\end{array}$ & T1 \\
\hline $\begin{array}{l}25.02 \\
\pm 2.67 \\
\end{array}$ & $\begin{array}{l}23.76 \pm 2 \\
.03\end{array}$ & $\begin{array}{l}22.71 \pm 4 \\
, 37\end{array}$ & $\begin{array}{l}21.88 \pm 2 \\
.02\end{array}$ & $\begin{array}{l}21.23 \pm 1 \\
.96\end{array}$ & \begin{tabular}{|l|}
20.10 \\
\pm 1.75 \\
\end{tabular} & $\begin{array}{l}19.22 \pm \\
1.45\end{array}$ & $\mathrm{~T} 2$ \\
\hline $\begin{array}{l}26.59 \\
\pm 2.97 \\
\end{array}$ & $\begin{array}{l}24.66 \pm 4 \\
.00\end{array}$ & $\begin{array}{l}23.86 \pm 1 \\
.84\end{array}$ & $\begin{array}{l}23.09 \pm 4 \\
.20\end{array}$ & $\begin{array}{l}22.50 \pm 4 \\
.15 \\
\end{array}$ & \begin{tabular}{|l|}
21.36 \\
\pm 4.01 \\
\end{tabular} & $\begin{array}{l}20.70 \pm \\
3.51\end{array}$ & T3 \\
\hline $\begin{array}{l}25.12 \pm 2 \\
.74\end{array}$ & $\begin{array}{l}23.85 \pm 0 \\
.85\end{array}$ & $\begin{array}{l}23.00 \pm 2 \\
.21\end{array}$ & $\begin{array}{l}22.82 \pm 2 \\
.08\end{array}$ & $\begin{array}{l}22.11 \pm \\
1.97\end{array}$ & $\begin{array}{l}21.21 \\
\pm 2.75\end{array}$ & $\begin{array}{l}20.10 \pm \\
3.21\end{array}$ & T4 \\
\hline N.S & N.S & N.S & N.S & N.S & N.S & N.S & Morale \\
\hline
\end{tabular}

Total and daily weight increases

Table (5) showed that there were no significant differences in the total weight gain by the results of the different experimental treatments dosed with different levels of kefir milk, despite the presence of a clear arithmetic increase for

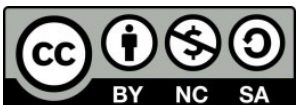

Page70

UTJagr This is an open access article under the CC-BY-NC-SA license (https://creativecommons.org/licenses/by-nc-sa/) 
the results of the dosed treatments compared to the control treatment, and the highest averages recorded for two treatments were $60 \mathrm{ml}$ of kefir milk/head/day And $40 \mathrm{ml}$ of kefir milk / head / day, which recorded averages (5.89 - 5.80) $\mathrm{kg}$, respectively, followed by the treatment of $80 \mathrm{ml}$ of kefir milk / head / day, and its average was (5.02) kg. As for the children of the control treatment, the averages of the total weight gain of their hens were the lowest, reaching ( 4.05$) \mathrm{kg}$ As for the daily weight visit, significant differences $(0.05 \leq \mathrm{P})$ were observed in the daily weight increases of the experimental treatment group dosed with $60 \mathrm{ml}$ of kefir milk / head / day and the average daily weight increase recorded was $(70.11(\mathrm{~g})$ followed by the treatment $40 \mathrm{ml}$ of kefir milk / head / A day where it recorded an average of (69.04) gm compared to the averages of the control treatment, which showed a clear decrease in the daily weight gain of its calves, and its recorded average was (48.21) gm and $80 \mathrm{ml}$ of kefir milk / head / day did not differ from the rest of the dosed treatments where it recorded (59.76) gm The reason for the weight gain of the treated animals that dosed kefir milk is attributed to the adaptation of the rumen environment to receive the new nutrients that are used to feed ruminants and thus enabled the availability of the appropriate types of microorganisms to digest the nutrients entering the rumen, as it increases the total and digesting bacteria of cellulose and reduces the lactate-producing bacteria, thus achieving benefit Maximum as a result of increased digestion of nutrients and an increase in the amount of microbial protein formed in addition to an increase in the level of glucose and the amount of energy formed, and thus this collectively improves weight gain (Al Ghalibi, 2010) (Al Ghalibi, 2015) (Farenzena, et al., 2016) and (Al Ghalibi 2017,a ) This study was in agreement with the study of Elaref et al. (2020), Chashinidel et al. 2020), (Ahmed et al., 2016), Al Ghalibi (2017, A) and Abu Salwa (2016).

Table (5) The total weight gain $(\mathrm{kg})$ and the daily weight gain ( $\mathrm{gm} /$ day) of the rams for a group of animals of control and groups dosed different levels of kefir milk for the duration of the study ( \pm standard deviation)

\begin{tabular}{|l|l|l|}
\hline $\begin{array}{l}\text { Daily weight gain } \\
\text { (g/day) }\end{array}$ & $\begin{array}{l}\text { Total weight } \\
\text { gain }(\mathrm{kg})\end{array}$ & Transactions \\
\hline $\mathbf{4 8 . 2 1 \pm 1 0 . 2 4} \mathrm{b}$ & $\mathbf{4 . 0 5 \pm 1 . 6 4}$ & T1 \\
\hline $\mathbf{6 9 . 0 4 \pm 9 . 2 6 a b}$ & $\mathbf{5 . 8 0 \pm 1 . 4 7}$ & T2 \\
\hline $\mathbf{7 0 . 1 1 \pm 1 1 . 6 3 ~ a}$ & $\mathbf{5 . 8 9} \pm 1.25$ & T3 \\
\hline $\mathbf{5 9 . 7 6 \pm 1 2 . 3 0 a b}$ & $\mathbf{5 . 0 2 \pm 1 . 1 2}$ & T4 \\
\hline 0.05 & N.S & Morale \\
\hline
\end{tabular}

\section{Feed intake and feed conversion efficiency}

Table (6) shows that there were no significant differences $(\mathrm{P} \leq 0.05)$ in the amount of feed eaten by kids of the different experimental treatments dosed with different levels of kefir milk, despite the presence of a clear arithmetic increase for

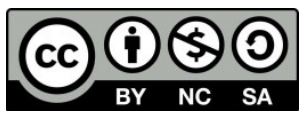


the performance of the dosed treatments compared to the control treatment, and the highest recorded averages were for the treatment of $60 \mathrm{ml}$ milk Kefir / head / day (59.98) kg, followed by the treatment $40 \mathrm{ml}$ of $\mathrm{kefir}$ milk / head / day, which recorded an average of (57.97) kg, followed by the treatment $80 \mathrm{ml}$ of kefir milk / head / day and it was an average of (55.74) kg, while the results of the control treatment were the average feed intake Of its children, the lowest averages, as it reached $(51.34) \mathrm{kg}$ As for the efficiency of food conversion, clear significant differences $(0.05 \mathrm{P} \leq)$ appeared for the results of the different experimental treatments that were dosed with different levels of kefir milk in Table (6). The significant increase was clear in favor of the results of the control treatment, which averaged (12.67) $\mathrm{kg}$ of feed / $\mathrm{kg}$ of weight gain compared to In the treatment of $40 \mathrm{ml}$ of kefir milk/head/day, whose average feed conversion efficiency was (9.82) $\mathrm{kg}$ of feed $/ \mathrm{kg}$ of weight gain, while the averages of feed conversion efficiency of the treatments of $60 \mathrm{ml}$ of kefir $\mathrm{milk} / \mathrm{head} /$ day and $80 \mathrm{ml}$ of kefir milk/head/day did not differ significantly from the mean The two control treatments and $40 \mathrm{ml}$ of kefir milk/head/day, and the averages recorded for the two treatments were $60 \mathrm{ml} \mathrm{of} \mathrm{kefir} \mathrm{milk/head/day}$ and $80 \mathrm{ml}$ of kefir milk/head/day $(10.11,11.10) \mathrm{kg}$ feed/ $\mathrm{kg}$ weight gain, respectively. The reason for the improvement in the efficiency of food conversion as a result of treating the goats with kefir milk, which is considered one of the types of vital enhancers, is attributed to its effective role in increasing rates and improving weight increases (Jang et al., 2009) and it works to increase the production of microbial protein in the rumen and amino acids processed for the ruminant animal. It is an increase in the amount of feed intake and an improvement in the ability to digest nutrients (Antonovic et al., 2006), and the reason can also be due to the fact that the dose of kefir milk works to provide a suitable environment for the growth of beneficial microorganisms, and then can lead to an increase in the numbers of cellulose-degrading protozoa, and then Maintaining the ideal $\mathrm{pH}$, which led to an increase in the utilization of starchy compounds of high nutritional value and easy to digest, which led to the provision of the goats' needs for perpetuation, growth and fattening, so their consumption of rough and concentrated feed was reduced, El.Shaer (2003).The results of the current study were in agreement with Al-Nassar (2017), Al-Ghalbi (2017,b), Ahmed and others (2016a), Al-Ghalbi (2010) and Al-Harees (2014), as they used the Iraqi bio-fortifier with proportions of 3 or $5 \%$ of the dry matter in feeding the Arabian lambs, which It contains some of the microorganisms such as lactic acid bacteria and bread yeast found in kefir.

Table (6) The feed intake to the goats and the efficiency of feeding the goats to the goats for a group of control animals and groups different levels of kefir milk were dosed for the duration of the study ( \pm standard deviation)

\begin{tabular}{|l|l|l|}
\hline $\begin{array}{l}\text { feed conversion } \\
\text { efficiency } \\
\text { For cattle (kg feed/kg weight } \\
\text { gain) }\end{array}$ & $\begin{array}{l}\text { Feed intake } \\
(\mathbf{k g}) \\
\text { Goats }\end{array}$ & Transactions \\
\hline $12.67 \pm 1.27 \mathrm{a}$ & 51.34 & $\mathrm{~T} 1$ \\
\hline $9.82 \pm 1.47 \mathrm{~b}$ & 56.97 & $\mathrm{~T} 2$ \\
\hline $10.11 \pm 1.31 \mathrm{ab}$ & 59.58 & $\mathrm{~T} 3$ \\
\hline
\end{tabular}


ISSN Onlin:2708-9347, ISSN Print: 2708-9339 Volume 10, Issue 2 (2021) PP 68-73

\section{https://jam.utq.edu.iq/index.php/main $\quad$ https://doi.org/10.54174/UTJagr.Vo10.N2/10}

\begin{tabular}{|l|l|l|}
\hline $11.10 \pm 1.09 \mathrm{ab}$ & 55.74 & T4 \\
\hline 0.05 & N.S & Morale \\
\hline
\end{tabular}

\section{REFERENCES}

1. Chashnidel, Yadollah; Bahari, Mehdi; Teimouri Yansari, Asadollah; Kazemifard, Mohammad (2020). The Effects of Dietary Supplementation of Prebiotic and Peptide on Growth Performance and Blood Parameters in Suckling Zell Lambs. Small Ruminant Research, (), 106121. doi:10.1016/j.smallrumres.2020.106121

2. Elaref, M.Y.; Hamdon, H.A.M.; Nayel, U.A.; Salem, A.Z.M.; Anele, U.Y. (2020). Influence of dietary supplementation of yeast on milk composition and lactation curve behavior of Sohagi ewes, and the growth performance of their newborn lambs. Small Ruminant Research, (), 106176. doi:10.1016/j.smallrumres.2020.106176 .

3. Enikeev, R. (2012). Development of a new method for determination of exopolysaccharide quantity in fermented milk products and its application in technology of kefir production. Food Chemistry, 134(4), $2437-$ 2441

4. Farenzena, R. et al(2016). Minimum length of the adaptation and collection period in digestibility trials with sheep fed ad libitum only forage or forage plus concentrate. Journal of Animal Physiology and Animal Nutrition.. Available from: <https:// onlinelibrary.wiley.com/doi/full/10.1111/jpn.12550>. Accessed: Oct. 23, 2019. doi: 10.1111/jpn.12550.

5. Farnworth E.R. (2005). Kefir - a complex probiotic. Food Science and Technology Bulletin: Functional Foods 2: 1-17. Fate of Levucal ${ }^{\circledR}$ Sc 1-1077 yeast additive during digestive transit doi: 10.1616/1476-2137.13938

6. Fuller, R. (1989) .A review, Probiotics in man and animals. J. Appl. Bacteriol., 66: 365-378.

7. Gaware ,V., K . Kotade , R . Dolas, K . Dhamak, S . somwanshi , V . Nikam and A.vivekanand kashid .(2011). The Magic of Kefir : A Review . pharmacologyonlin . 1:376-386

8. Golowczyc M.A. , P. Mobili , G.L. Garrote, A.G. Abraham , G.L. De Antoni.(2007). Protective action of Lactobacillus kefir carrying S-layer protein against Salmonella enterica serovar Enteritidis . International Journal of Food Microbiology 118 264-273.

9. Güzelseydim, Z. B., Kok-Tas, T., Greene, A. K., \& Seydim, A. C. (2011). Review: functional properties of kefir. Critical Reviews in Food Science \& Nutrition, 51(3), 261-268.

10. Haghpanah T.Sheibani V. Afarinesh M.R.(2012). Effect of Kefir consumption on spatial learning and memory consolidation in adult male rats. Pharmaceutical Sciences. 18( 1) : $43-50$.

11. Hsieh, H. H., Wang, S. Y., Chen, T. L., Huang, Y. L., \& Chen, M. J. (2012). Effects of cow's and goat's milk as fermentation media on the microbial ecology of sugary kefir grains. International Journal of Food Microbiology, 157(1), 73-81

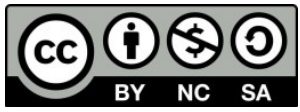

Page73

UTJagr This is an open access article under the CC-BY-NC-SA license (https://creativecommons.org/licenses/by-nc-sa/) 
ISSN Onlin:2708-9347, ISSN Print: 2708-9339 Volume 10, Issue 2 (2021) PP 68-73

12. Irigoyen, A., Arana, I., Castiella, M., Torre, P. and Ibanez, F.C. (2005). Microbiological,physicochemical, and sensory characteristics of kefir during storage. Food Chemistry 90:613-620.

13. Nagpal, R., Puniya, A.K., Puniya, M., Dhewa, T., Sehgal, J. P. and Singh, K. (2007). A strategy to improve ruminant productivity through direct-fed microbials. In: Maheshwari DK and Dubey RC (eds.). Biotechnology of agricultural microorganisms: an agro-industrial approach. India: IK International Pvt. Ltd, New Delhi.

14. Otles, S. and Cagindi, O., 2003. Kefir: a probiotic dairy composition, nutritional and therapeutic aspects. Pakistan Journal of Nutrition, 2, 54-59 